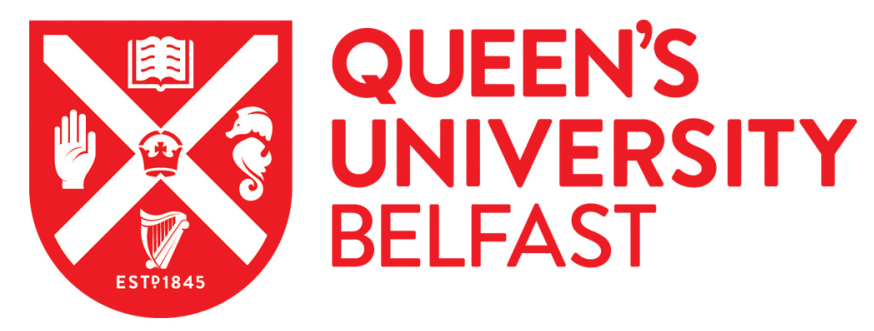

\title{
Alternatives to antibiotics-a pipeline portfolio review
}

Czaplewski, L., Bax, R., Clokie, M., Dawson, M., Fairhead, H., Fischetti, V. A., Foster, S., Gilmore, B., Hancock, R. E. W., Harper, D., Henderson, I. R., Hilpert, K., Jones, B. V., Kadioglu, A., Knowles, D., Ólafsdóttir, S., Payne, D., Shaunak, S., Silverman, J., ... Rex, J. H. (2016). Alternatives to antibiotics-a pipeline portfolio review. The Lancet Infectious Diseases, 16(2), 239-251. https://doi.org/10.1016/S1473-3099(15)00466-1

Published in:

The Lancet Infectious Diseases

Document Version:

Peer reviewed version

Queen's University Belfast - Research Portal:

Link to publication record in Queen's University Belfast Research Portal

Publisher rights

(C) 2016 The Lancet

\section{General rights}

Copyright for the publications made accessible via the Queen's University Belfast Research Portal is retained by the author(s) and / or other copyright owners and it is a condition of accessing these publications that users recognise and abide by the legal requirements associated with these rights.

Take down policy

The Research Portal is Queen's institutional repository that provides access to Queen's research output. Every effort has been made to ensure that content in the Research Portal does not infringe any person's rights, or applicable UK laws. If you discover content in the Research Portal that you believe breaches copyright or violates any law, please contact openaccess@qub.ac.uk. 


\title{
Czaplewski L, et al. Alternatives to antibiotics - a pipeline portfolio review.
}

The Lancet Infectious Diseases 2016; published online January 12.

\author{
http://www.thelancet.com/journals/laninf/article/PIIS1473-3099(15)00466-1/abstract
}

http://dx.doi.org/10.1016/S1473-3099(15)00466-1

\section{Copy of the accepted manuscript before Lancet editing:}

\section{Alternatives to antibiotics - a pipeline portfolio review}

Lloyd Czaplewski, Richard Bax, Martha Clokie, Mike Dawson, Heather Fairhead, Vincent A. Fischetti, Simon Foster, Brendan F. Gilmore, Robert E.W. Hancock, David Harper, Ian R. Henderson, Kai Hilpert, Brian V Jones, Aras Kadioglu, David Knowles, Sigríður Ólafsdóttir, David Payne, Steve Projan, Sunil Shaunak, Jared Silverman, Christopher M. Thomas, Trevor J. Trust, Peter Warn, John H. Rex.

Dr Lloyd Czaplewski PhD; Chemical Biology Ventures Ltd. Abingdon, UK, Abgentis Ltd, Birmingham, UK and Persica Pharmaceuticals Ltd, Canterbury, UK. Dr Richard Bax MD; Transcrip Partners LLP. Reading, UK. Professor Martha Clokie PhD; Dept. of Infection, Immunity and Inflammation, University of Leicester, UK. Dr Mike Dawson PhD; Novacta Biosystems Ltd. Welwyn Garden City, UK and Cantab Anti-infectives Ltd. Welwyn Garden City, UK. Dr Heather Fairhead PhD; Phico Therapeutics Ltd. Babraham, UK. Professor Vincent A. Fischetti PhD; Laboratory of Bacterial Pathogenesis and Immunology. The Rockefeller University, New York, USA. Professor Simon Foster PhD; Department of Molecular Biology and Biotechnology, University of Sheffield, Sheffield. UK and Absynth Biologics Ltd. Liverpool, UK. Professor Brendan F Gilmore PhD; School of Pharmacy, Queen's University, Belfast. UK. Professor Robert E.W. Hancock PhD; Department of Microbiology and Immunology. University of British Columbia, Vancouver, Canada. Dr David Harper PhD; Evolution Biotechnologies, Bedfordshire, UK. Professor Ian Henderson PhD; Institute of Microbiology and Infection, University of Birmingham, UK. Dr Kai Hilpert PhD; Institute of Infection and Immunity, St Georges, University of London. UK., TiKa Diagnostics Ltd. UK. Dr Brian Jones PhD; School of Pharmacy and Biomolecular Sciences, University of Brighton UK and Queen Victoria Hospital NHS Foundation Trust, East Grinstead, UK. Professor Aras Kadioglu PhD; Institute of Infection and Global Health, University of Liverpool, UK. Dr David Knowles $\mathrm{PhD}$; Procarta Biosystems Ltd. Norwich, UK and Absynth Biologics Ltd. Liverpool, UK. Dr Sigríður Ólafsdóttir PhD; Icelandic Medicines Agency, Reykjavik, Iceland. Dr David Payne PhD; GlaxoSmithKline, Collegeville, PA, USA. Dr Steve Projan PhD; MedImmune, LLC Gaithersburg MD. USA. Professor Sunil Shaunak MD; Department of Medicine. Imperial College, London. UK. Dr Jared Silverman PhD; Kaleido Biosciences, Cambridge MA. USA. Professor Christopher M. Thomas PhD; Institute of Microbiology and Infection, University of Birmingham, UK and Plasgene Ltd. UK, Dr Trevor J. Trust PhD; Pan-Provincial Vaccine Enterprise Inc. Canada. Dr Peter Warn PhD; Evotec Ltd, Manchester, UK. Dr John H. Rex MD; AstraZeneca, Boston, MA USA and F2G Ltd, Manchester, UK.

Correspondence to: Dr Lloyd Czaplewski, Chemical Biology Ventures Ltd. 123 Alexander Close, Abingdon. OX14 1XD. UK. Lloyd.czaplewski@chembioventures.com 


\begin{abstract}
For 70 years antibiotics have saved countless lives and enabled the development of modern medicine, but it is becoming clear that the success of antibiotics may have only been temporary and we now anticipate a long-term, generational and perhaps never-ending challenge to find new therapies to combat antibiotic-resistant bacteria. As the search for new conventional antibiotics has become less productive and there are no clear strategies to improve success, a broader approach to address bacterial infection is needed. This review of potential alternatives to antibiotics (A2As) was commissioned by the Wellcome Trust, jointly funded by the Department of Health, and involved scientists and physicians from academia and industry. For the purpose of this review, A2As were defined as non-compound approaches (that is, products other than classical antibacterial agents) that target bacteria or approaches that target the host. In addition, the review was limited to agents that had potential to be administered orally, by inhalation or by injection for treatment of systemic/invasive infection. Within these criteria, the review has identified 19 A2A approaches now being actively progressed. The feasibility and potential clinical impact of each approach was considered. The most advanced approaches (and the only ones likely to deliver new treatments by 2025) are antibodies, probiotics, and vaccines now in Phase II and Phase III trials. These new agents will target infections caused by $P$. aeruginosa, $C$. difficile and $S$. aureus. However, other than probiotics for $C$. difficile, this first wave will likely best serve as adjunctive or preventive therapies. This suggests that conventional antibiotics will still be needed. The economics of pathogen-specific therapies must improve to encourage innovation, and greater investment into A2As with broad-spectrum activity (e.g. antimicrobial-, host defense- and, anti-biofilm peptides) is needed. Increased funding, estimated at $>£ 1.5$ bn over 10 years is required to validate and then develop these A2As. Investment needs to be partnered with translational expertise and targeted to support the validation of these approaches at Clinical Phase II proof of concept. Such an approach could transform our understanding of A2As as effective new therapies and should provide the catalyst required for both active engagement and investment by the pharma/biotech industry. Only a sustained, concerted and coordinated international effort will provide the solutions needed for the next decade.
\end{abstract}




\section{Introduction}

Given the rise of antibacterial resistance and the challenges of conventional antibacterial agent discovery and development that have led to a very limited pipeline of new therapies, especially for Gram-negative bacterial infections, it may be prudent to consider the potential of non-conventional approaches. ${ }^{1-2}$ A review delivered by 24 scientists from academia and industry was commissioned by the Wellcome Trust and jointly funded by the Department of Health to consider the prospects for alternatives to antibiotics (A2As). While there have been technical reviews of individual alternative approaches, ${ }^{3}$ this review seeks to define the current state of A2As at the portfolio level, prioritise approaches, and provide evidence-based expectations for their delivery in order to inform funding decisions and policy in this crucial area of healthcare.

A2As were defined as non-compound approaches (that is, products other than classical antibacterial agents) that target bacteria or approaches that target the host. Thus an antibody targeting a virulence factor or quorum sensing would be included but a compound targeting these processes would not. ${ }^{4,5}$ Biologicals or compounds targeting the host were included. This review focused on therapies that could be developed to treat systemic/invasive rather than superficial infections and is therefore limited to therapies that are administered orally, by inhalation or by injection. External topical administration was beyond its scope. The primary objective was to identify and review prospective therapeutic replacements for antibiotics. Alternatives that could be used in combination with conventional antibiotics and prophylactic approaches were also considered.

The review considered 1 . Feasibility of informative clinical trials; 2 . Magnitude of medical potential; 3 . Likelihood and consequences of resistance; 4. Level of current research activity; 5. Likely timeline to registration, and 6. Activities that might enable validation and progression. The review process comprised (a) preparation of a $\sim 50-$ page working document summarising 19 current A2A within the scope of the review, (b) a meeting to review and prioritise approaches, and (c) collective preparation of a report for the funders which is summarised in this review. This allowed the group to compile and share broad and well-informed views on the state-of-the-art for A2As with a wider community.

\section{Text Box 1. Search strategy and selection criteria}

The review benefited from expert summaries and non-confidential information on approaches and projects provided by its members as well as comprehensive literature and database searching which was used to identify approaches, projects, companies and publications to inform the group. All current and ongoing projects identified that were within scope were included in the portfolio review. Historic projects informed the review but were not included in the portfolio analysis.

Preclinical and clinical projects were identified through a series of searches of PubMed, the internet using Google and ClinTrials.gov up to 27 February 2015, by use of key terms such as "antibody", "probiotic", "lysin", "bacteriophage", "vaccines", "antimicrobial peptide", "lantibiotic", "host defense peptide", "innate defense peptide", "antibiofilm peptide", "immunomodulation", "immune stimulation", "immune suppression", "vaccine", "liposome", "chelation" and, if necessary, their use with "E. coli OR $P$. aeruginosa OR K. pneumoniae OR A. baumannii OR C. difficile OR S. aureus OR infection OR bacteria" followed by inspection of the papers and top 30 websites listed. Once proteins or compounds (Tables 1 and 2) and the organization developing them had been identified, their names were used for additional searches e.g. "Merck". "MedImmune", "Aridis", "Seres", "Rebiotix", "Shire", "Viropharma", "Intron Biotechnology", "ContraFect", "Ampliphi”, "Phico", "Akthelia", "Sanofi Pasteur", "Valneva", "Pfizer", "Roche", "Novacta", "Adenium" and the associated company website overview, pipeline and news pages. The state of alternative project pharmacology was assessed by searches of PubMed for articles to 27 February 2015 by use of terms "pharmacokinetic OR safety" with "human OR mouse OR rat" in combination with "host defense peptide"; "antibiofilm peptide"; "lantibiotic"; "bacteriophage"; "lysin" and in the case of antimicrobial peptides "antimicrobial peptide" with "pharmacokinetic OR safety" and "E. coli OR P. aeruginosa OR C. difficile OR S. aureus" followed by inspection of the 238 papers listed. We also reviewed studies cited in articles identified by this search and included them when relevant. The primary focus of the review was on non-compound approaches that target bacteria and any approaches that target the host to provide alternatives to antibiotics and to address antibiotic resistance. Projects using compounds to directly target bacteria were excluded. This meant that compound-based approaches 
targeting efflux pumps, regulators of transcription and antibiotic resistance breakers were excluded from this review. During the Lancet ID review process and in response to reviewer comments the searches were repeated and additional references added. Literature on potential modulators of innate immunity was identified by PubMed searching "TLR2, TLR4, NLRP3, AIM2, C5-cleavage" each in combination with "E. coli OR P. aeruginosa OR K. pneumoniae OR A. baumanii OR C. difficile OR S. aureus OR infection OR bacteria". The titles of the first 500 papers for each search were inspected for relevance and selected papers reviewed in detail. In addition, searches were refined by adding additional key words "agonist OR agonist OR inhibitor OR monoclonal OR polyclonal OR knockout" and the first 200 paper titles inspected for relevance. Further searches including the list of bacteria along with "innate immunity antibiotic resistance" with or without the keywords "TLR2, TLR4, NLRP3, AIM2, C5-cleavage" were performed and the first 200 paper titles inspected for relevance. Group members also provided key relevant references on modulating innate immunity that were known to them.

\section{The portfolio of alternative approaches}

The group identified 19 A2A approaches for consideration and recognised that the list may be incomplete (Tables 1 and 2). Projects were not reviewed in sufficient detail to make individual funding recommendations. Technical feasibility and clinical potential of the approaches were considered at a high level across all the projects but the commercial attractiveness, potential return on investment, or potential for reimbursement of specific projects were not analyzed. Given the wide range of views within the group, this review does not represent a unanimous consensus. We recognise that perspectives differ, that there are gaps in available data, and that science will continue to advance. This review should be taken as a snapshot of A2As and their perceived potential. Ten alternatives were prioritised and considered in more detail (Table 1). The other 9 approaches were not prioritised at this time because (i) other projects were considered more advanced in the translational pipeline and/or (ii) there was insufficient peer-reviewed information to assess their potential clinical impact, feasibility, or safety (Table 2).

The potential of the top 10 approaches, with the exception of the recently discovered antibiofilm peptides, has been known for more than a decade but has not led to therapeutic breakthroughs for systemic treatments for reasons that are not entirely clear. ${ }^{104} \mathrm{New}$ vaccines have been the most notable successes but are of course prophylatic. ${ }^{105}$

The top 10 approaches which the group considered merited attention were placed into two tiers. The focus within Tier 1 was on clinical development and in Tier 2 on preclinical development over the next 5 years. The main reason peptides are not included in Tier 1 is that virtually all clinical trials to date were for topical usage while this review considers largely systemic usage. Success of Tier 1 projects in Phase II and Phase III studies could transform the perception of the A2As portfolio. Access to funding through key preclinical and clinical development steps (e.g. production and characterisation, formulation, pharmacokinetics and pharmacodynamics, toxicology and safety pharmacology) with subsequent publications showing how these data support continued drug development was considered to be critical to progress towards clinical validation and to build confidence in the field. Supported studies should define and test clear go/no-go decision points for product progression. Primarily in vitro programmes of work or those focused entirely on surrogate endpoints e.g. characterising cytokines rather than pathology or microbiology may not be competitive.

Application of "major pharma" development resources and expertise will be critical to validation and progression of A2As in a timely manner. Reliance on the academic and biotech communities alone may not be sufficient to provide new products within a decade. Application of best practices in the definition of target product profiles, rigorous target validation, understanding bacterial species and strain differences, the mechanisms and consequences of resistance, differences in rodent and human responses, time and resources to adequately optimise and characterise potential products as they progress through in vitro and in vivo efficacy, safety and toxicology assays will all collectively contribute to a greater chance of success or at least enable definitive and evidencebased decisions to stop exploring unproductive approaches.

Unfortunately, and in contrast to classical antibiotics, the predictive value of preclinical studies for host-directed therapies may be limited. In particular, some A2As act via the immune system and this may mean that greater 
preclinical use of non-human primates will be required. ${ }^{106}$ This all increases risk and averts funding. However, failure of the early clinical studies should not be allowed to block future exploitation.

Based on a combination of high clinical impact and high technical feasibility, the approaches anticipated to have the greatest potential to provide A2As were: (a) phage lysins as replacements; (b) vaccines as prophylactics; (c) antibodies as prophylactics, and (d) probiotics as treatments or prophylactics for Clostridium difficile- and antibiotic- associated diarrhoea (CDAD/AAD). Bacteriophages (wild-type and engineered) were also considered to have potentially high impact as replacements but the feasibility of their entry into the market was unclear. Selected immune stimulation approaches were considered feasible as broad-spectrum prophylactics or adjuncts to conventional treatments but their clinical impact was also unclear at this time.

Because of their potential for broad-spectrum activity, it was disappointing to find that antimicrobial peptides were best placed in Tier 2 rather than Tier 1. Antimicrobial peptides have been tested in clinical trials and failed but the tested products were focused on topical applications and, as such, are outside the scope of this review. The reasons for peptide "failure" at Phase III clinical trials and non-progression to product registration include lack of efficacy, non-superiority over standard care antibiotics and safety and it should be noted that the underlying reasons for these clinical outcomes have not been reported. ${ }^{107} \mathrm{We}$ speculate that early attempts to deliver new therapies, and in particular peptides, were hampered by lack of investment, use of non-optimised peptides and insufficient development and clinical expertise.

Some may consider past failure indicative of poor prospects for peptide-based therapies but the group took the longer term view that A2As, including peptides, are still an emerging field. For instance, there appear to be only 6 published pharmacology studies (two for plectasin, two for lantibiotics and two for other peptides) in the antimicrobial peptide field, and two published safety studies across the fields of lysin, bacteriophage, antimicrobial-, host defense- and, antibiofilm- peptides. ${ }^{108-115}$ Thus, the literature base does not suggest a mature field. Most of the preclinical characterisation of projects remains proprietary with insufficient published peerreviewed evidence to understand the pharmacokinetic, pharmacodynamics, toxicology and safety strengths and liabilities of these approaches. Revisiting past programmes and applying new methods of PK/PD modelling could indicate improvements in dose regimens that could alter the outcome of new clinical trials. ${ }^{116}$ Regulatory approaches to antibacterials also continue to evolve and may in the future permit narrowly focused programs in which some of these agents might better succeed. ${ }^{117}$

\section{A2As portfolio analysis}

To enable an evidence-based review of the current state of development and likelihood of success of the prioritised alternative approaches, extensive internet searching and knowledge within the working party were used to define the breadth (number of projects and targets) and depth (current phase of development) of the A2As portfolio. In particular, company websites and news releases were used to identify projects currently (Q1 2015) being actively progressed (Table 3). As companies quickly announce positive news but there may be a delay between companies halting projects and announcing project cessation in press releases or on websites, the project list is considered inclusive and likely to overstate rather than understate the active project portfolio.

Industry standard timelines for clinical development phases (Phase I - 1 year, Phase II - 2 years, Phase III - 3 years, and Registration - 1 year) were used to estimate the earliest likely date of product registration. ${ }^{1,132-133}$ The estimated year of registration will thus likely differ from a particular sponsor's estimates or project timelines. Host defense peptides and antibiofilm peptides were excluded because they were too early for this analysis.

Similarly, industry-standard probabilities of success across projects in different phases of development(preclinical to Phase I - 23\%, Phase $1-45 \%$, Phase II - 47\%, Phase III - 71\%, and Registration - 90\%) were applied. ${ }^{1,132-}$ ${ }^{133}$ The estimates of the probability of success for individual projects within the class were summed. Values $>100 \%$ for a given category indicate that there are sufficient project numbers and/or project maturity to anticipate that at least one product could be registered if access to sufficient funding and skilled development resources is provided.

Industry standard costs for clinical development phases (Phase I - £6m, Phase II - £10m, Phase III - £45m, and Registration $-£ 1.3 \mathrm{~m}$ ) were used to estimate the cost of portfolio projects. ${ }^{1,132-133}$ As with timing projections, the resulting estimated costs will likely differ from a particular sponsor's estimates. 
This uniform approach was taken because (a) similar levels of project planning data are not available for all projects, (b) when available, project-specific timelines developed by sponsors often shift, and (c) use of standard timelines allows uniform (re)calculation of the data as required.

The strength of this type of analysis is that it removes any personal bias but its weakness is that it is almost always incorrect in the specifics of its details.

Analysed by approach, the pipeline for antibodies, probiotics and vaccines was sufficient to anticipate success as the probability of registration is $>100 \%$. However, for other alternative areas there are too few projects ongoing and/or they are currently too early to allow for anticipated project attrition. For instance, on the basis of the current portfolio, we cannot assume that lysins, bacteriophages or antimicrobial peptides will contribute to new therapies.

It is important to note that most of the current novel activity is focused on C. difficile, P. aeruginosa and S. aureus only. The timeline analysis suggests that if successful, registrations might be: antibodies - 2017; probiotics 2018; vaccines - 2019; immune stimulants 2021; lysins and antimicrobial peptides - 2022; bacteriophages - 2023; and host defense and antibiofilm peptides from 2027 onwards.

When analysed by pathogen, the 'probability of success' analysis indicates that if the alternative portfolio is adequately funded, we could expect two new products (antibody, probiotic or vaccine) for CDAD/AAD by 2019; one for P. aeruginosa (antibody or vaccine) by 2021, and one for S. aureus (antibody, lysin, or vaccine) by 2022. The current portfolio lacks sufficient breadth and depth to anticipate multiple new products for these pathogens during this time frame. It is a matter of concern that there is little activity on the other ESKAPE pathogens (e.g., Enterococcus, Klebsiella, Acinetobacter or Enterobacter) or directed towards other Enterobacteriaceae. This indicates that it is most unlikely that A2As for these life-threatening pathogens, and others, will emerge in the next 10 years.

As the portfolio advances through the later development phases, costs will increase and innovative funding arrangements will be required to maintain momentum given that most pharma companies have withdrawn from the "antibiotic arena".

The group recognised that by 2018/2019 we could anticipate observing success in multiple projects at Phase II and that this could encourage greater investment in the sector. New projects starting in 2018/2019 might be expected to reach registration by 2030 .

The group found that A2As have the potential to deliver clinical benefit but the scale of current activity and availability of funding will have to increase substantially to achieve that benefit.

\section{What will the portfolio cost?}

To estimate funding requirements, the named projects from Table 3 were budgeted to 2025 using industry standard costs for clinical development phases. Although some organisations may currently aim to deliver with smaller budgets, the application of standard costs serves to reflect prior reality for delivery and to remove bias.

The funds for the current phase of the project are assumed to be in place and committed. By adding the cost of each subsequent stage that each project has to pass up to registration and application of the risk estimates at each stage of development, as described above, the risk-adjusted funds required to registration were calculated.

Where the alternative project portfolio is too thin or early to anticipate success, additional funding is required to strengthen the portfolio. A key objective should be to test A2As at Phase II to validate the approach. To adequately understand the clinical potential of an approach it may be necessary to take several projects that represent the approach into Phase II. The lysins, bacteriophage and antimicrobial peptides approaches have advancing projects but there are currently too few projects to be able to anticipate adequate testing of the concepts. They require additional investment to build capacity and translational expertise to exploit their full potential.

Allowing for anticipated project attrition, a pipeline to support the evaluation of a single project at Phase II would require 9 preclinical projects at $£ 12.5 \mathrm{~m} /$ project over 5 years, leading to two Phase I and potentially one Phase II study with a total budget of $£ 135 \mathrm{~m}$. Any funding should be dependent on the results being peer reviewed and accessible via open access publication to provide the requisite evidence-base to inform future R\&D. 
The host defense and antibiofilm peptide approaches are attractive because of their broad spectrum potential. It may be necessary to advance the first wave of these innovative projects beyond Phase II to validate the approaches and to convince pharma, investors and clinicians. A greater level of investment $(£ 575 \mathrm{~m})$ would be required to build a pipeline of host defense peptide and antibiofilm peptide projects because they are currently in an early stage of development. An estimated 34 preclinical projects are required to provide 8 Phase I and 4 Phase II studies to get at least one project through to Phase III and product registration (Table 4). There are several natural and synthetic host defense peptides and antibiofilm peptides as potential starting points. Chemical modifications, hybrid peptides and chemical mimetics could be explored. ${ }^{134,135}$ Project creation and translational research in this area could be accelerated by committing $£ 85 \mathrm{~m} /$ year for 5 years. This would provide a powerful incentive to build capacity and to progress towards clinical validation of these peptide based approaches.

Our analysis assumes that funding for named projects of $£ 227 \mathrm{~m}$ is available to complete their progression through their current project phase. Additional risk adjusted funding of $£ 48 \mathrm{~m}$ will be required for subsequent phases and should support development of one new product for each of $P$. aeruginosa, $C$. difficile and $S$. aureus by 2022. This level of investment would enable validation of antibodies, probiotics, and novel vaccines as A2As.

The lysin, bacteriophage and antimicrobial peptide portfolios need to be increased in order to adequately test these approaches in a timely manner. This could be achieved with risk adjusted investment of $£ 405 \mathrm{~m}$. Building an adequate host defense peptide and antibiofilm peptide portfolio will require $£ 604 \mathrm{~m}$.

The working party therefore identified $\sim £ 1.5$ billion of risk-adjusted funding that will be required to validate and exploit the current 10 high priority A2A approaches in a timely manner. We did not forecast the funding requirements for the remaining 10 approaches or for additional blue-sky activity to add to the pipeline in the future.

\section{Challenges to developing and deploying A2As}

\section{Innovation must be linked to translation expertise}

The innovators in this space (largely academics and biotechs) often lack industry-level development and clinical skills. Hence, increased funding needs to be partnered with investment in translational skills development. A2A programmes may benefit from greater access to PK/PD, formulation, toxicology and manufacturing expertise. Provision of adequate funding for the multi-disciplinary teams and costs associated with the preclinical characterization and delivery of competitive lead candidates for clinical development will be a critical factor for success. Pre-competitive partnerships and the creation of development hubs might be one way to support this area. Calls to tender for and purchase desired research and development activities from contract research organisations and pharma on behalf of the academic and SME/biotech alternative community is another innovative way to support this area. Such activities might encourage industry to become involved in a manner that develops both critical mass and sustainability.

\section{Clinical Trials}

Careful clinical trial design will be critical. Projects need to ensure that endpoints are relevant to both the patient and the physician, often but not necessarily exclusively based on endpoints grounded in how patients feel, function and survive. Unless the clinical signal is strong, there is a risk that the size and cost of the clinical trials required to demonstrate an incremental benefit will be too large to support. Thus, it will be important to be willing to terminate projects if clinical success is either low probability or likely to have low impact. This could have been one reason for the cessation of previous peptide trials. As with trials of new antibiotics, surrogate endpoints that are predictive of clinical efficacy should be included as secondary endpoints (e.g., changes in cytokine levels or changes in imaging of infections) but are unlikely to be acceptable as the basis for registration for life-threatening infections.

\section{Economic models in this therapy area must be improved}

In addition to adequate funding and expertise, development and deployment of alternative antibacterial medicines is dependent on a return on investment. The working party did not consider the economics of A2As but noted that replacing antibiotics will be a major challenge. At present, many of the A2As are pathogen- or strain-specific. By comparison, most modern antibiotics have a broad spectrum of activity. For example, the recently approved combination of ceftolozane and tazobactam, for cIAI, cUTI and pyelonephritis, has clinical efficacy data for 10 pathogens including Klebsiella spp, Escherichia coli and Pseudomonas aeruginosa with clinical microbiology 
suggesting potential against another 20 pathogens. ${ }^{136,137}$ Multiple alternative therapies would be required to provide similar spectrum of coverage. In the first instance, A2As are likely to focus on the most prevalent infections and may provide sufficient clinical benefit to ensure a return on investment. At best, they will be a partial replacement for antibiotics.

\section{Diagnostics/Theranostics}

The future role of innovative diagnostics, their use in combination with innovative targeted therapies (sometimes referred to as "theranostics") and the likelihood or timescale of their delivery and costs were not within the scope of this review. However, the group recognised that for single species targeted therapies, these enablers will be critical for widespread clinical use and patient benefit and that their introduction into clinical practice would be a strong support as well for improved antibiotic stewardship. ${ }^{138}$

\section{Innovative regulation}

Innovative therapies may require innovative regulation. ${ }^{117}$ Bacteriophage therapies currently in development are an example of the kind of product driving the evolution of regulatory approaches. Broad conversations about options for the unique challenges of each alternative are required: a recent workshop hosted by EMA on bacteriophage is an example of how this work needs to be progressed. ${ }^{139}$

\section{Flexible delivery models}

Some A2As could be delivered by different mechanisms to those currently used for traditional antibiotics. Instead of a single global manufacturing pipeline, the development of localised services akin to blood transfusion or stem cell harvesting and transplantation could facilitate patient benefit and should be considered. For example, localised bacteriophage therapy attuned to patient need within a hospital might be an appropriate model for some products.

\section{One Health: the potential for alternatives in animal health}

All of the A2As have potential uses in animal health and demonstration of efficacy in companion and agricultural animals could be important steps in de-risking an approach before its clinical development in humans. The anticipated costs for many of the approaches may however, be prohibitive for animal use. Commitment to substantial subsidies may be required to incentivise alternative development for animal health where their use could contribute to reduction in antibiotic use. Epibiome is an example of a company targeting animal health with bacteriophages before human use but their programmes are too early to be included in this review. ${ }^{140}$

\section{Conventional antibiotics will still be needed}

At least initially, many of the A2As are likely to be trialled and used as adjuncts to antibiotics because their activities may not provide sufficient therapeutic benefit on their own. While effective antibiotics are still available it may prove difficult to demonstrate superiority over standard of care when comparing an antibiotic with an antibiotic plus an $\mathrm{A} 2 \mathrm{~A}$ adjunct treatment. If resistance to the antibiotic develops, then its use in combination therapies will be compromised. A2As which are primarily adjunctive therapies may have narrow window of opportunity in which to demonstrate benefit. In the longer term, it may be possible to demonstrate that combinations of A2A therapies could be used without antibiotics.

\section{We anticipate that deployment of Alternatives will:}

I. In some cases entail reliance on improved and faster diagnostic technology to enable targeting of individual bacterial species, or even strains of species, rather than clinical indications.

II. Be more often used for prophylaxis than for treatment.

III. Require multiple products to replace a single antibiotic.

IV. Involve substantially higher costs than for traditional antibiotics.

V. Require access to sufficient and sustained funding to enable timely R\&D and prompt clinical evaluation.

\section{Future outlook}

The objective of this portfolio review was to define which Alternatives to Antibiotics are most likely to deliver new therapies with clinical utility. The group recognised that academic researchers and industry have successfully generated a diverse portfolio of potential A2As comprising projects from preclinical optimisation to Phase III 
studies and prioritised 10 approaches for more detailed review. The field is still emerging and holds promise provided that adequate funding is available to build capacity and a preclinical evidence-base is created to enable prioritisation and to progress optimised drugs to critical Phase II validation.

There was little doubt that the field might deliver new medicines for P. aeruginosa, S. aureus and C. difficile. However, other than probiotics for $C$. difficile, this first wave of new agents is likely to serve best as adjunctive or preventive therapy. Therefore, traditional antibiotics will still be required.

If we have to depend on A2As in the future, we need to build capacity now and substantially increase the throughput of projects. ${ }^{141}$ The working party estimated that the priority A2A approaches alone require an investment of at least $£ 1.5 \mathrm{bn}$, committed in the next 5 years and spent within 10 years to initiate a pipeline of translational projects that would deliver these new therapies. An investment of this scale will enable a better understanding of which approaches are most likely to deliver and ideally identify those that will not. Additional investment will be required to bring products to market and into clinical use. Longer term significant and sustainable funding will be required to advance and exploit the wider A2A portfolio. Policy and funding must now be linked. Without adequate funding we must assume that new treatments to replace and/or supplement antibiotics will not be available for more than a decade, if at all, and the consequences of such a prolonged delay for global healthcare systems needs to be considered now. Our analysis of just a subset of all of the activities that could contribute towards the fight against antimicrobial resistance suggests that funding is now the key limiting factor that is stalling a global response. Antimicrobial resistance has to become a major international science programme in order to deliver the solutions that society needs now. By comparison the Large Hadron Collider project cost $\sim £ 6$ bn and the International Space Station $£ 96 \mathrm{bn} .{ }^{142,143}$ Antimicrobial research and development to address the problem of antibiotic resistance probably requires an effort somewhere between the two.

\section{Key Messages (as a text box)}

- Alternatives to antibiotics: Non-compound approaches that target bacteria or approaches that target the host to treat bacterial infection

- Academics and industry have created at least 19 approaches that need to be further evaluated

- Understanding the potential of A2As will require experimental clinical medicine and not just drug discovery

- Enhanced translational expertise must be deployed to aid validation and progression of these A2As

- Exemplar projects must be advanced to Clinical Phase II to enable validation of approaches

- Antimicrobial resistance needs to grow into big science to deliver new innovative therapies

- The Large Hadron Collider project cost $\sim 6 b n$ and the International Space Station $£ 96 b n$ : antimicrobial research and development to address the problem of antibiotic resistance probably requires an effort somewhere between the two.

\section{Contributors}

LC formed the A2A working group and defined the focus of the review. LC and JHR co-chaired the group and prepared the first draft of the review. All members contributed to provision of literature searching, analysis and interpretation of findings and especially knowledge around their area(s) of expertise. A sub-group comprising LC, BFG, IRH, BVJ, AK, H-HK, SO, SS, TJT and JHR edited the drafting of the review before wider input from the group. LC and JHR finalised the manuscript taking the editorial suggestions of the group into account.

\section{Role of the funding source}

LC received a fee which was co-funded by the Wellcome Trust and the Department of Health to provide a review into alternatives to antibiotics. The fee enabled LC to reimburse working group travel, hotel and subsistence expenses to attend a meeting to review A2As and compensation to LC and JHR for managing the review process and preparation of the manuscript. LC had final responsibility for the content of the manuscript and for submitting it to Lancet ID. The Wellcome Trust and the Department of Health acted as observers and did not influence the content or conclusions of the review.

\section{Declaration of interests}

Given the aims of this review process, many of the contributors were selected because they had (and will continue to develop) conflicts of interest with respect to companies and products mentioned in this report. Connections to 
related companies based on employment at the time the report was prepared are as noted in the summary of authors. LC is a Director of Chemical Biology Ventures Ltd, and Abgentis Ltd and an employee of Persica Pharmaceuticals Ltd. MC consults and collaborated with AmpliPhi Biosciences Corporation. MD is a Director/ Shareholder in Novacta Biosystems Ltd and a Director of Cantab Anti-infectives Ltd. HF is a Director/Shareholder in Phico Therapeutics Ltd. VAF Consults and is a Shareholder in ContraFect Inc.. SF is a Director/Shareholder and Consultant for Absynth Biologics Ltd. REWH has licensed projects to Elanco, is on the SAB of Adenium Pharmaceuticals and is the founder and major shareholder in ABT Innovations Inc. DH is a former employee and a current Shareholder in AmpliPhi Biosciences Corporation. KH is a Director of TiKa Diagnostics Ltd. BJ is on the SAB of Hutman Diagnostics AG. DK is Chairman of Absynth Biologics Ltd and Procarta Biosystems Ltd. DP is an employee/Shareholder in GSK. SP is an employee of MedImmune and a Shareholder in AstraZeneca. SS is a Founder/Shareholder in Abzenza plc. SO is a former Shareholder in Akthelia. CT is a Director of Plasgene Ltd. PW is an employee of Evotec a CRO that performs work with A2A companies. JHR is an employee/Shareholder in AstraZeneca, a consultant to F2G Ltd, and a consultant to Advent Life Sciences (an investor in F2G Ltd). Of note, AstraZeneca does own MedImmune, but SP manages the MedImmune products mentioned in Table 3 and JHR was not otherwise connected with them at the time of this review. Finally, JHR accepted an offer to become a non-Executive Director of Adenium Biotech ApS after the review had been accepted for publication. JS is a non-exec Director of Auspherix Ltd. LC and JHR received remuneration from The Wellcome Trust and the Department of Health for chairing the Working Party and managing the preparation of the report and this review.

\section{Acknowledgments}

This review was commissioned by the Wellcome Trust and jointly funded by the 'Department of Health's Policy Research Programme'. 


\section{Tables}

Table 1. Prioritised alternative approaches

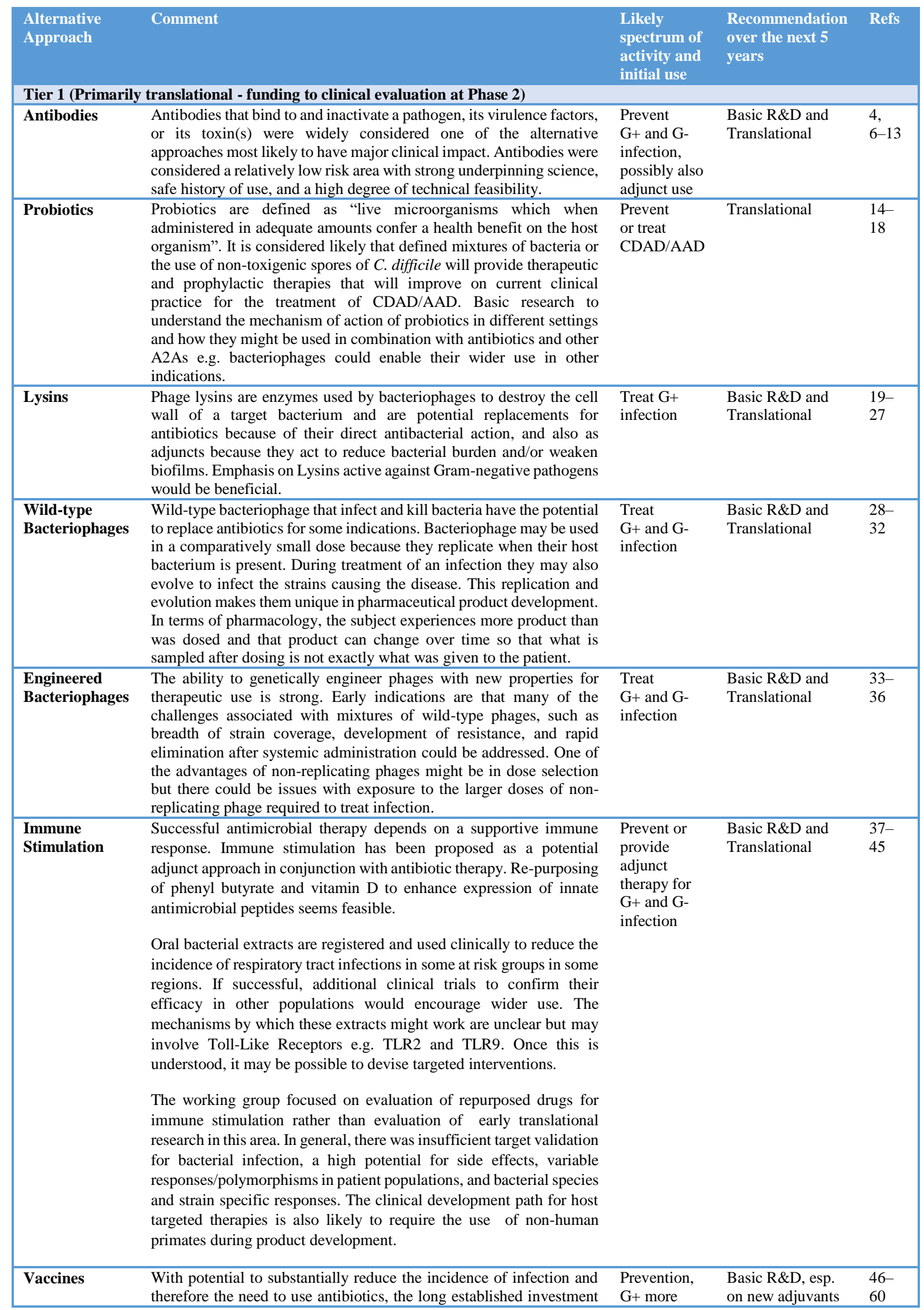




\begin{tabular}{|c|c|c|c|c|}
\hline & $\begin{array}{l}\text { in vaccines for new targets should continue. Given the ageing human } \\
\text { population, we need better knowledge of the potential for vaccination } \\
\text { in the elderly and how to dose to achieve protection in immune } \\
\text { compromised individuals. }\end{array}$ & $\begin{array}{l}\text { than G- } \\
\text { infection }\end{array}$ & & \\
\hline \multicolumn{5}{|c|}{ Tier 2 (strong support for judicious funding while monitoring for breakthrough insights regarding systemic therapy) } \\
\hline $\begin{array}{l}\text { Antimicrobial } \\
\text { Peptides } \\
\text { (AMPs) }\end{array}$ & $\begin{array}{l}\text { The advantages of AMPs are their broad spectrum activity which } \\
\text { includes most major Gram-negative and Gram-positive bacteria; their } \\
\text { bactericidal and rapid action; low target-based resistance and their } \\
\text { lack of immunogenicity. The extensive academic literature and early } \\
\text { clinical trials have not yet led to a therapeutic breakthrough for } \\
\text { systemic treatments. It will require studies aimed at understanding } \\
\text { why they have largely not been utilized systemically (e.g. toxicity, } \\
\text { cost, lability to proteases, etc) and how to overcome these deficiencies } \\
\text { (e.g. formulation, redesign or use of non-natural amino acids, etc). In } \\
\text { some instances topical application e.g. by aerosol might supplement } \\
\text { systemic therapy. The reasons why projects were stopped are not in } \\
\text { the public domain. Public-private partnerships to fund and test the } \\
\text { potential of AMPs in well-designed clinical trials and to publish the } \\
\text { outcomes will be necessary to inform future investment into this } \\
\text { approach. }\end{array}$ & $\begin{array}{l}\text { Treat or } \\
\text { Adjunct for } \\
\text { G+ and G- } \\
\text { infection }\end{array}$ & Translational & $\begin{array}{l}61- \\
72\end{array}$ \\
\hline $\begin{array}{l}\text { Host/Innate } \\
\text { Defense } \\
\text { Peptides } \\
\text { (HDPs/IDRs) }\end{array}$ & $\begin{array}{l}\text { Host defense peptides and innate defense regulators are small natural } \\
\text { peptides or synthetic peptides respectively, which have indirect } \\
\text { antimicrobial effects. They act primarily by increasing expression of } \\
\text { anti-inflammatory chemokines and cytokines, and by reducing the } \\
\text { expression of pro-inflammatory cytokines. Additional resources are } \\
\text { required to accelerate their preclinical evaluation and progression into } \\
\text { clinical trials to provide clinical validation of the approach. Targeting } \\
\text { host responses could carry a greater risk and introduce the } \\
\text { complication of distinguishing and understanding the immunological } \\
\text { differences between rodents and humans at the population level. }\end{array}$ & $\begin{array}{l}\text { Adjunct for } \\
\text { G+ and G- } \\
\text { infection }\end{array}$ & Basic R\&D & $\begin{array}{l}36 \\
73- \\
76\end{array}$ \\
\hline $\begin{array}{l}\text { Antibiofilm } \\
\text { Peptides }\end{array}$ & $\begin{array}{l}\text { Peptides that specifically inhibit bacterial biofilm formation have been } \\
\text { identified and are in preclinical development. Their use as adjunctive } \\
\text { therapy could improve outcomes. }\end{array}$ & $\begin{array}{l}\text { Adjunct for } \\
\text { G+ and G- } \\
\text { infections }\end{array}$ & Basic R\&D & $\begin{array}{l}77 \\
78\end{array}$ \\
\hline
\end{tabular}

G+ = Gram-positive, G- = Gram-negative, Basic R\&D = provide support for fundamental research and preclinical proof of concept studies to validate approaches and extend into early translational work to characterise efficacy, pharmacology, pharmacodynamics and preliminary toxicology so that potential liabilities can be defined. Translational $=$ focus support on bringing products into the clinic. 
Table 2: Additional alternative approaches

\begin{tabular}{|c|c|c|}
\hline Alternative Approach & Comment & Refs \\
\hline Immune Suppression & $\begin{array}{l}\text { A bacterial infection can lead to an excessive host innate immune response (ranging from the } \\
\text { systemic inflammatory response syndrome (SIRS) to septic shock) in which the injury to the } \\
\text { host is made much worse by the host's pro-inflammatory cytokine response. Selective } \\
\text { manipulation of this cytokine response has the potential to be used in synergy with antibiotics } \\
\text { to reduce pathogen-induced tissue damage mediated by cytokines and neutrophils, and to } \\
\text { accelerate the time to patient recovery. The medical need is high but past failures of Phase III } \\
\text { clinical trials, despite promising preclinical, Phase I and Phase II data, suggests that this area of } \\
\text { sepsis and septic shock carries a great risk and has therefore not been prioritised. New concepts } \\
\text { are needed to develop novel small as well as large molecule drugs for this high mortality area } \\
\text { of infection whose incidence is increasing. In contrast to antibiotics, the healthcare sector } \\
\text { would pay a large premium for a drug that was effective at reducing morbidity and mortality. } \\
\text { The immune system is complex and changing the balance of pro- and anti-inflammatory } \\
\text { activities in the context of bacterial infection in order to achieve a therapeutic benefit will } \\
\text { require new paradigms of thinking in systems biology. A detailed academic review of this area } \\
\text { was beyond the scope of this review. }\end{array}$ & $\begin{array}{l}36 \\
79-82\end{array}$ \\
\hline $\begin{array}{l}\text { Anti-resistance nucleic } \\
\text { acids }\end{array}$ & $\begin{array}{l}\text { Antibiotic resistance genes are frequently spread by highly transmissible plasmids, particularly } \\
\text { in Gram-negative pathogens. Effective removal of resistance genes could resensitise bacteria to } \\
\text { conventional antibiotics. Some perceive that this approach may not reach all of the resistance } \\
\text { targets in a complex environment (e.g. gut or abscess) in the absence of selection, while } \\
\text { containment of a transmissible genetically modified vector that delivers the anti-resistance } \\
\text { nucleic acid in an open system could face significant regulatory challenges. }\end{array}$ & $83-88$ \\
\hline $\begin{array}{l}\text { Antibacterial nucleic } \\
\text { acids }\end{array}$ & $\begin{array}{l}\text { The use of nucleic acids to directly kill bacteria is being explored in a variety of formats in both } \\
\text { academia and biotech. In terms of their therapeutic potential, studies are at an early stage. At } \\
\text { the very least, these tools will continue to be developed to support fundamental microbial } \\
\text { genetics studies. }\end{array}$ & $87-89$ \\
\hline $\begin{array}{l}\text { Toxin sequestration using } \\
\text { liposomes }\end{array}$ & $\begin{array}{l}\text { Pathogens often secrete toxins that damage mammalian cells and drive inflammation. } \\
\text { Administration of liposomes to act as decoys for toxin binding has been shown to reduce } \\
\text { damage to cells and reduce disease severity. }\end{array}$ & 90 \\
\hline $\begin{array}{l}\text { Antibiotic-degrading } \\
\text { enzymes to reduce } \\
\text { selection of resistance }\end{array}$ & $\begin{array}{l}\text { When antibiotics are eliminated via the gut, exposure of the normal gut bacteria to the } \\
\text { antibiotic may lead to development of resistance and drive CDAD/AAD. Phase II studies } \\
\text { demonstrate that oral beta-lactamase can destroy beta-lactams in the faeces. The perceived } \\
\text { challenge of demonstrating the clinical benefit of degrading enzyme administration at Phase III } \\
\text { led to this approach not being prioritised. }\end{array}$ & $91-94$ \\
\hline Metal Chelation & $\begin{array}{l}\text { Bacterial pathogens require zinc, manganese and iron ions to fully express their } \\
\text { pathogenicity/virulence, biofilm formation and multiple essential enzymatic and metallo-beta } \\
\text { lactamase activities. Metal chelation may deny pathogens these key processes. Discussion with } \\
\text { pharmacologists and toxicologists suggests that this approach is speculative and could present } \\
\text { safety concerns. }\end{array}$ & $95-99$ \\
\hline Alphamers & $\begin{array}{l}\text { Alphamers are immune modifiers comprising an } \alpha \text {-Gal epitope fused to a bacterial pathogen } \\
\text { binding aptamer to redirect endogenous anti-Gal antibodies to the pathogen and hence enhance } \\
\text { immune clearance. }\end{array}$ & 100 \\
\hline $\begin{array}{l}\text { Apheresis of protective } \\
\text { antibodies }\end{array}$ & $\begin{array}{l}\text { In some patients with } P \text {. aeruginosa lung infection, antibodies bind to the pathogen and protect } \\
\text { it from serum-mediated killing. Depletion of these antibodies restores the ability of serum to } \\
\text { kill bacteria and initial clinical data suggest an improved clinical outcome. }\end{array}$ & 101 \\
\hline $\begin{array}{l}\text { Immune Stimulation by } \\
\text { P4 Peptide }\end{array}$ & $\begin{array}{l}\text { Phagocytic killing of bacteria can be enhanced by P4 Peptide, a chemically synthesised } 28 \\
\text { amino acid peptide derived from the } S \text {. pneumoniae surface exposed virulence factor PsaA. P4 } \\
\text { peptide stimulates opsonophagocytic uptake and killing in invasive disease models of } S \text {. } \\
\text { pneumoniae infection in mice. The combination of P4 intranasally and i.p. IgG provided } 100 \% \\
\text { survival in the mouse model and significantly reduced bacterial burden. A therapy based on P4, } \\
\text { IgG and antibiotic is proposed. However, additional evidence may be required to support the } \\
\text { use of iv IgG in severe pneumonia. The project recently received MRC DPFS funding to } \\
\text { progress to Phase I studies. }\end{array}$ & $\begin{array}{l}102 \\
103\end{array}$ \\
\hline
\end{tabular}


Table 3. A2A Portfolio Review as at Q1 2015

\begin{tabular}{|c|c|c|c|c|c|}
\hline Approach & $\begin{array}{l}\text { Probability of } \\
\text { Registration by } \\
2025^{+} \text {and Sponsor }\end{array}$ & $\begin{array}{l}\text { Risk Adjusted Cost of } \\
\text { Projects } \\
\text { (current/subsequent } \\
\text { phases) } \\
\text { and Target }\end{array}$ & $\begin{array}{l}\text { Pipeline investment to } \\
\text { enable additional Phase } 2 \\
\text { validation", Name and ref. }\end{array}$ & Phase at Q1 2015 & $\begin{array}{l}\text { Earliest } \\
\text { Anticipated } \\
\text { Registration* }\end{array}$ \\
\hline \multirow[t]{8}{*}{ Antibodies } & $183 \%^{+}$ & $£ 60 \mathrm{~m} / £ 120 \mathrm{~m}$ & - & & \\
\hline & Merck & C. difficile & Bezlotoxumab $^{119,120}$ & P3 ongoing & 2017 \\
\hline & MedImmune & S. aureus & MEDI48936,120 & P2 ongoing & 2021 \\
\hline & Aridis & P. aeruginosa & AR-101 ${ }^{121}$ & P2a complete & 2021 \\
\hline & Aridis & S. aureus & $\mathrm{AR}-301^{121}$ & P2a ready & 2022 \\
\hline & MedImmune & P. aeruginosa & MEDI3902 ${ }^{9}$ & P1 ongoing & 2023 \\
\hline & XBiotech & S. aureus & $514 \mathrm{G} 3^{13}$ & P1 ongoing & 2023 \\
\hline & Aridis & P. aeruginosa & Aerucin $^{10}$ & IND ready & 2025 \\
\hline \multirow[t]{4}{*}{ Probiotics } & $124 \%+$ & $£ 52 \mathrm{~m} / £ 53 \mathrm{~m}$ & - & & \\
\hline & Seres & C. difficile & SER-109 $9^{122}$ & $\mathrm{P} 3$ ready & 2018 \\
\hline & Rebiotix & C. difficile & RBX2660 & P2 ongoing & 2019 \\
\hline & Shire (Viropharma) & C. difficile & VP20621 $1^{124}$ & $\mathrm{P} 2$ ready & 2022 \\
\hline \multirow[t]{3}{*}{ Lysins } & $26 \%+$ & $£ 12 \mathrm{~m} / £ 28 \mathrm{~m}$ & $£ 135 m$ & & \\
\hline & $\begin{array}{l}\text { Intron } \\
\text { Biotechnology }\end{array}$ & S. aureus & SAL200 27 & P1 ongoing & 2022 \\
\hline & ContraFect & S. aureus & $\mathrm{CF}-301^{19}$ & P1 ongoing & 2022 \\
\hline Bacteriophages & $9 \%+$ & $£ 13 m / £ 57 m$ & $£ 135 \mathrm{~m}$ & & \\
\hline \multicolumn{6}{|l|}{ Wild-type } \\
\hline & AmpliPhi & C. difficile & AmpliPhage- $004^{125}$ & Pre-P1 & 2023 \\
\hline & AmpliPhi & $P$. aeruginosa & AmpliPhage- $001^{125}$ & Pre-P1 & 2023 \\
\hline \multicolumn{6}{|l|}{ Engineered } \\
\hline & Phico Therapeutics & $P$. aeruginosa & PT-3.1 $1^{36}$ & Pre-P1 & 2023 \\
\hline \multirow{3}{*}{$\begin{array}{l}\text { Immune } \\
\text { Stimulation }\end{array}$} & $43 \%^{+}$ & $£ 0 \mathrm{~m} / £ 55 \mathrm{~m}$ & - & & \\
\hline & Akthelia & C. difficile & Phenylbutyrate/vitD 38,40 & $\mathrm{P} 2$ ready & 2021 \\
\hline & - & Various & Bacterial extracts $^{43}$ & P1 ready & 2022 \\
\hline \multirow[t]{5}{*}{ Vaccines } & $188 \%+$ & $£ 74 \mathrm{~m} / £ 66 \mathrm{~m}$ & - & & \\
\hline & Sanofi Pasteur & C. difficile & C. difficile toxoid vaccine $\mathrm{e}^{126}$ & P3 & 2019 \\
\hline & Valneva & P. aeruginosa & $\mathrm{IC}_{4} 3^{127,128}$ & P2/P3 ongoing & 2019 \\
\hline & Valneva & C. difficile & $\mathrm{IC} 84^{128}$ & P2 ongoing & 2021 \\
\hline & Pfizer & S. aureus & $\mathrm{SA}_{4} \mathrm{Ag}^{129}$ & $\mathrm{P} 2$ ready & 2021 \\
\hline \multirow{6}{*}{$\begin{array}{l}\text { Antimicrobial } \\
\text { Peptides }\end{array}$} & $52 \%+$ & $£ 16 \mathrm{~m} / £ 104 \mathrm{~m}$ & $£ 135 m$ & & \\
\hline & Roche & P. aeruginosa & POL7080 ${ }^{130}$ & P2 ongoing & 2022 \\
\hline & Novacta Biosystems & C. difficile & NVB302 $2^{131}$ & P1 ongoing & 2022 \\
\hline & Adenium & S. aureus & AP- $138^{64}$ & Pre-P1 & 2023 \\
\hline & Adenium & $U T I$ & AP- $139^{64}$ & Pre-P1 & 2023 \\
\hline & Adenium & C. difficile & AP- $114^{64}$ & Pre-P1 & 2023 \\
\hline \multirow[t]{2}{*}{ Other Peptides } & - & - & $£ 604 \mathrm{~m}$ & & \\
\hline & - & Gram-ve and Gram+ve & - & Preclinical & 2027 \\
\hline
\end{tabular}

The A2A portfolio contains 25 projects representing 8 alternative approaches from preclinical to Phase III studies at 18 companies from 6 countries. The probability of registration for a single project is estimated by multiplying the probabilities of success through each stage of development from its current position to successful registration. The probability of registration of a product from an approach is estimated by summing the individual project probabilities. An approach with a probability of registration greater than or equal to $100 \%$ suggests that if adequate funding and expertise is applied across the projects, then successful registration is anticipated from that category. The risk-adjusted cost of each project was estimated by applying standard project risks at each stage to the standard costs for each phase of development. The risk-adjusted cost for the approach was estimated by summing the individual project risk-adjusted costs. The cost per approach assumes that companies have the funds for the current phase of the project but have to justify the need for additional funds for further product development. The pipeline investment is an estimate of the funding required to enable new project activity to expand those approaches with insufficient activity to adequately test the concept of the approach at Phase II. The current phase of the projects, and if successful, the earliest date that registration can be 
anticipated using standard metrics is shown. The group note that funding of $\sim £ 160 \mathrm{~m}$ into these projects has been secured during the last 12 months. ${ }^{13,26,122,125}$

Table 4: Estimate of the project pipeline cost for Host Defense and Antibiofilm peptides

\begin{tabular}{|lllllll|}
\hline Phase & Preclinical & Phase I & Phase II & Phase III & Registration & Total \\
\hline Stage probability of success & $23 \%$ & $45 \%$ & $47 \%$ & $71 \%$ & $90 \%$ \\
\hline Number of projects & 34 & 8 & 4 & 2 & 1 & \\
\hline Cost of Phase $\mathbf{~ m}$ & 12.5 & 6 & 10 & 45 & 1.3 & 1.3 \\
\hline Portfolio cost $\mathbf{~} m$ & 425 & 48 & 40 & 90 & $£ 604$ \\
\hline
\end{tabular}

The calculation used to estimate the costs of funding a relatively new alternative approach to provide sufficient number of preclinical projects to survive standard rates of attrition and to have a reasonable chance of product registration is shown. 


\section{References}

1. Payne, DJ, Gwynn, MN, Holmes, DJ, Pompliano, DL. Drugs for bad bugs: confronting the challenges of antibacterial discovery Nat Rev Drug Discov. 2007; 6(1): 29-40

2. Tommasi, R, Brown, DG, Walkup, HK, Manchester, JI, Miller, AA. ESKAPEing the labyrinth of antibacterial discovery. Nature Reviews Drug Discovery. Published online 3 July 2015; doi:10.1038/nrd4572

3. Gill, E, Franco, OL, Hancock, REW. Antibiotic Adjuvants: Diverse Strategies for Controlling Drug-Resistant Pathogens. Chem Biol Drug Des 2015; 85: 56-78

4. Palliyil, C, Downham, I, Broadbent, K et al. High-Sensitivity Monoclonal Antibodies Specific for Homoserine Lactones Protect Mice from Lethal Pseudomonas aeruginosa Infections. Applied and Environmental Microbiology 2014; 80(2): 462-4691

5. Starkey, M, Lepine, F, Maura, D et al. Identification of anti-virulence compounds that disrupt quorum-sensing regulated acute and persistent pathogenicity. PLoS Pathog. 2014; 10(8):e1004321

6. Hua, L, Hilliard, JJ, Shi, Y et al. Assessment of an Anti-Alpha-Toxin Monoclonal Antibody for Prevention and Treatment of Staphylococcus aureus-Induced Pneumonia. Antimicrob. Agents Chemother. 2014; 58(2): 11081117

7. Lu, Q, Rouby, J-J, Laterre, PF et al. Pharmacokinetics and safety of panobacumab: specific adjunctive immunotherapy in critical patients with nosocomial Pseudomonas aeruginosa $\mathrm{O} 11$ pneumonia. J Antimicrob Chemother 2011; 66: 1110-1116

8. Secher, T, Fas, S, Fauconnier, L et al. The Anti-Pseudomonas aeruginosa Antibody Panobacumab Is Efficacious on Acute Pneumonia in Neutropenic Mice and Has Additive Effects with Meropenem. 2013; PLOS ONE 8(9): e73396.

9. DiGiandomenico, A, Keller, AE, Gao, C et al. A multifunctional bispecific antibody protects against Pseudomonas aeruginosa. Science Translational Medicine 2014; 6(262): 262ra155

10. www.arsanis.com

11. Szijártó, V, Guachalla, LM, Visram, ZC, Hartl, K, Varga, C, Mirkina, I, Zmajkovic, J, Badarau, A, Zauner, G, Pleban, C, Magyarics, Z, Nagy, E, Nagy, G. Bactericidal monoclonal antibodies specific to the lipopolysaccharide O antigen from multidrug-resistant Escherichia coli clone ST131-O25b:H4 elicit protection in mice. Antimicrob Agents Chemother. 2015; 59(6):3109-16.

12. http://www.bellushealth.com/English/projects/Shigamab-for-sHUS/default.aspx

13. http://www.xbiotech.com/clinical/mrsa.html

14. Guidelines for the evaluation of probiotics in food. Report of a Joint FAO/WHO Working Group on Drafting Guidelines for the Evaluation of Probiotics in Food; Ontario, Canada. April 30 - May 1, 2002

15. Villena, J, Kitazawa, H. Modulation of Intestinal TLR4-Inflammatory Signaling Pathways by Probiotic Microorganisms: Lessons Learned from Lactobacillus jensenii TL2937. Front Immunol. 2013; 4: 512

16. Kotzampassi, K, Giamarellos-Bourboulisb. EJ. Probiotics for infectious diseases: more drugs, less dietary supplementation. International Journal of Antimicrobial Agents 2012; 40: 288- 296

17. Goldenberg, JZ, Ma, SSY, Saxton, JD. et al. Probiotics for the prevention of Clostridium difficile associated diarrhea in adults and children (Review). The Cochrane Library 2013, Issue 5.

18. Bo, L, Li, J, Tao, T et al. Probiotics for preventing ventilator-associated pneumonia (Review) The Cochrane Library 2014, Issue 10.

19. Schuch, R, Lee, HM, Schneider, BC et al. Combination therapy with lysin cf-301 and antibiotic is superior to antibiotic alone for treating MRS-induced murine bacteremia. J. Infect. Diseases. 2013; 209(9): 1469-1478 
20. Yang, H, Yu, J, Wei, H. Engineered bacteriophage lysins as novel anti-infectives. Frontiers in Microbiology 2014; 5 Article 542

21. Briers, Y, Walmagh, M, Puyenbroeck, VV et al. Engineered Endolysin-Based "Artilysins" To Combat Multidrug-Resistant Gram-Negative Pathogens. mbio.asm.org 2014; 5(4) e01379-14

22. Lai, MJ, Lin, NT, Hu, A et al. Antibacterial activity of Acinetobacter baumannii phage $\phi$ AB2 endolysin (LysAB2) against both gram-positive and gram-negative bacteria. Appl Microbiol Biotechnol. 2011; 90(2): 529539

23. Pastagia, M, Schuch, R, Fischetti, VA, Huang, D. Lysins: the arrival of pathogen-directed anti-infectives. J. Med Microbiol. 2013; 2(10): 1506-1516

24. Lood, R, Winer, BY, Pelzek AJ et al. , Novel phage lysin capable of killing the multidrug resistant Gramnegative bacterium Acinetobacter baumannii in a mouse bacteremia model. Antimicrob Agents Chemo. 2015; Published ahead of print AAC.04641-14

25. Schuch, R, Lee, HM, Schneider, BC. Combination Therapy With Lysin CF-301 and Antibiotic Is Superior to Antibiotic Alone for Treating Methicillin-Resistant Staphylococcus aureus-Induced Murine Bacteremia. J Infect Dis. 2013; (9): 1469-78.

26. www.contrafect.com

27. Jun, SY, Jung, GM, Yoon, SJ et al Preclinical Safety Evaluation of Intravenously Administered SAL200 Containing the Recombinant Phage Endolysin SAL-1 as a Pharmaceutical Ingredient. Antimicrobial Agents and Chemotherapy 2014; 58(4) 2084-2088

28. Abedon, ST, Kuhl SJ, Blasdel, BG, Kutter, ME. "Phage Treatment of Human Infections" in Bacteriophage. 2011; 1(2):66-85

29. Smith, W, Huggins, MB. Successful Treatment of Experimental Escherichia coli Infections in Mice Using Phage: its General Superiority over Antibiotics. Journal of General Microbiology 1982; 128: 307-318

30. Smith, W, Huggins, MB. Effectiveness of phages in treating experimental Escherichia coli diarrhoea in calves, piglets and lambs. J Gen Microbiology 1983; 129: 2659-2675

31. Morgan, AD, Maclean, RC, Buckling A. Effects of antagonistic coevolution on parasite-mediated host coexistence. J. Evol. Biol. 2009; 2(2): 287-292

32. Wright, A, Hawkins, CH, Anggard, EE, Harper, DR. A controlled clinical trial of a therapeutic bacteriophage preparation in chronic otitis due to antibiotic-resistant Pseudomonas aeruginosa; a preliminary report of efficacy. Clinical Otolaryngology 2009; 34: 349-357

33. Fairchild, H. SASP gene delivery: a novel antibacterial approach. Drug News Perspect. 2009; 22(4): $197-203$.

34. http://www.phicotx.co.uk/wp-content/uploads/2014/12/F1550.pdf.29.

35. http://www.phicotx.co.uk/wp-content/uploads/2014/12/F1548.pdf.

36. Lu, TK, Collins. JJ. Dispersing biofilms with engineered enzymatic bacteriophage. PNAS 2007; 104: $11197-$ 11202

37. Hancock, REW, Nijnik, A, Philpott, DJ. Modulating immunity as a therapy for bacterial infections. Nature Rev. Microbiol. 2012; 10: 243-254

38. Raqib, R, Sarker, P, Bergman, P et al. Improved outcome in shigellosis associated with butyrate induction of an endogenous peptide antibiotic. Proceedings of the National Academy of Sciences 2006; 103(24): 9178-9183

39. Sarker, P, Mily, A, Al Mamun, A et al. Ciprofloxacin Affects Host Cells by Suppressing Expression of the Endogenous Antimicrobial Peptides Cathelicidins and Beta-Defensin-3 in Colon Epithelia. 2014; Antibiotics 3(3): 353-374 
40. Bergman, P, Norlin, A-C, Hansen, S et al. Vitamin D3 supplementation in patients with frequent respiratory tract infections: a randomised and double-blind intervention study. BMJ Open 2012; 2:e001663.

41. Kulkarni, NN, Yi, Z, Huehnken, C, Agerberth, B, Gudmundsson, GH. Phenylbutyrate induces cathelicidin expression via the vitamin D receptor: Linkage to inflammatory and growth factor cytokines pathways. Molecular immunology 2015; 63(2): 530-539

42. Mily, A, Rekha, RS, Kamal, SM, et al. Oral intake of phenylbutyrate with or without vitamin D3 upregulates the cathelicidin LL-37 in human macrophages: a dose finding study for treatment of tuberculosis. BMC pulmonary medicine 2013; 13(1): 23

43. Del-Rio-Navarro, BE, Espinosa-Rosales, FJ, Flenady, V, Sienra-Monge, JJL. Immunostimulants for preventing respiratory tract infection in children (Review). Cochrane Reviews 2006; 7: 629-717

44. Duggan, JM, You, D, Cleaver, JO, Larson, DT, Garza, RJ, Guzmán Pruneda, FA, Tuvim, MJ, Zhang, J, Dickey, BF, Evans, SE. Synergistic interactions of TLR2/6 and TLR9 induce a high level of resistance to lung infection in mice. J Immunol. 2011; 186(10): 5916-5926

45. BenMohamed, F, Medina, M, Wu, Y-Z, Maschalidi, S, Jouvion, G, et al. Toll-Like Receptor 9 Deficiency Protects Mice against Pseudomonas aeruginosa. Lung Infection. PLoS ONE 2014; 9(3): e90466

46. Hampton, LM, Farley, MM, Schaffner, W et al. Prevention of antibiotic-nonsusceptible Streptococcus pneumoniae with conjugate vaccines. J. Infect. Dis. 2012; 205: 401-411

47. Centers for Diseases Control. Progress toward eliminating Haemophilus influenzae type b disease among infants and children - United States, 1987-97. MMWR 1998; 47: 993-8

48. Palmu, AA, Jokinen, J, Nieminen, $\mathrm{H}$ et al. Effect of pneumococcal Haemophilus influenzae protein D conjugate vaccine (PHiD-CV10) on outpatient antimicrobial purchases: a double-blind, cluster randomised phase 3-4 trial. Lancet Infect. Dis. 2014; 14: 205-212

49. MRC Review of Vaccines Research, 2014: www.mrc.ac.uk/documents/doc/mrc-review-of-vaccines-research2014/

50. Bak, H, Rathkjen, P. Reduced use of antimicrobials after vaccination of pigs against porcine proliferative enteropathy in a Danish SPF herd. Acta Vet. Scand. 2009; 51: 1

51. Matthews, L, Reeve, R, Gally DL et al. Predicting the public health benefit of vaccinating cattle against Escherichia coli O157. PNAS. 2013; 110: 16265-16270

52. Centers for Disease Control and Prevention. Antibiotic Resistance Threats in the United States, 2013. http://www.cdc.gov/drugresistance/threat-report-2013/.

53. Aguiar, SI, Serrano, I, Pinto, FR et al. Changes in Streptococcus pneumoniae serotypes causing invasive disease with non-universal vaccination coverage of the seven-valent conjugate vaccine. Clin Microbiol Infect. 2008; 14(9): 835-43

54. Jones, D. Reverse vaccinology on the cusp. Nature Reviews Drug Discovery. 2012; 11: 175-176

55. von Mentzer, A, Connor, TR, Wieler, LH et al. Identification of enterotoxigenic Escherichia coli (ETEC) clades with long-term global distribution. Nature Genetics. 2014; 46: 1321-1326

56. Moriel, DG, Bertoldi, I, Spagnuolo, A et al. Identification of protective and broadly conserved vaccine antigens from the genome of extraintestinal pathogenic Escherichia coli. PNAS. 2010; 107: 9072-9077

57. Cozzi, R, Scarselli, M, Ferlenghi, I. Structural vaccinology: a three-dimensional view for vaccine development. Curr. Top. Med. Chem. 2013; 13: 2629-37

58. Nuccitelli, A, Cozz, i R, Gourlay, LJ et al. Structure-based approach to rationally design a chimeric protein for an effective vaccine against Group B Streptococcus infections. PNAS. 2011; 108: 10278-10283

59. NIH News. 2014. NIH Awards Seven New Vaccine Adjuvant Discovery Contracts.http://www.niaid.nih.gov/news/newsreleases/2014/Pages/vaccineadjuvantawards.aspx. 
60. DiazGranados, CA, Dunning, AJ, Kimmel, M et al. Efficacy of high-dose versus standard-dose Influenza vaccine in older adults. N Engl J Med 2014; 371: 635-645

61. Fjell, CD, Hiss,JA, Hancock, REW, Schneider, G. Designing antimicrobial peptides: Form follows function. Nature Rev. Drug Discov. 2012; 11: 37-51

62. Hilchie, AL, Wuerth, K, Hancock, REW. Immune modulation by multifaceted cationic host defense (antimicrobial) peptides. Nature Chem. Biol. 2013; 9: 761-768

63. Zhang, Y, Teng, D, Mao, R, et al. High expression of a plectasin-derived peptide NZ2114 in Pichia pastoris and its pharmacodynamics, postantibiotic and synergy against Staphylococcus aureus. Appl Microbiol Biotechnol. 2014; 98(2): 681-94

64. www.adeniumbiotech.com

65. Walter, JFM, Velden, WJ, van Iersel, TM et al. Safety and tolerability of the antimicrobial peptide human lactoferrin 1-11 (hLF1-11). BMC Med 2009; 7: 44

66. Srinivas, N, Jetter, P, Ueberbacher, BJ et al. Peptidomimetic Antibiotics Target Outer-Membrane Biogenesis in Pseudomonas aeruginosa. Science 2010; 327: 1010-1013

67. Sandiford, SK. Perspectives on lantibiotic discovery - where have we failed and what improvements are required? Expert Opin Drug Discov. 2015; 19:1-6

68. Papareddy P, Kasetty G, Kalle, M, Bhongir, RK, Mörgelin, M, Schmidtchen, A, Malmsten, M. NLF20: an antimicrobial peptide with therapeutic potential against invasive Pseudomonas aeruginosa infection. J Antimicrob Chemother. 2015 [Epub ahead of print]

69. Lin, L, Nonejuie, P, Munguia, J, Hollands, A, Olson, J, Dam, Q, Kumaraswamy, M, Rivera, H Jr4, Corriden, R, Rohde, M, Hensler, ME, Burkart, MD, Pogliano, J, Sakoulas, G, Nizet, V. Azithromycin Synergizes with Cationic Antimicrobial Peptides to Exert Bactericidal and Therapeutic Activity Against Highly MultidrugResistant Gram-Negative Bacterial Pathogens. EBioMedicine. 2015; 10;2(7):690-8

70. Soren, O, Brinch, KS, Patel, D, Liu, Y, Liu, A, Coates, A, Hu, Y. Antimicrobial Peptide Novicidin Synergizes with Rifampin, Ceftriaxone, and Ceftazidime against Antibiotic-Resistant Enterobacteriaceae In Vitro. Antimicrob Agents Chemother. 2015; 59(10):6233-40

71. Krizsan, A, Prahl, C, Goldbach, T, Knappe, D, Hoffmann, R. Short Proline-Rich Antimicrobial Peptides Inhibit Either the Bacterial 70S Ribosome or the Assembly of its Large 50S Subunit. Chembiochem. 2015; 16(16):2304-8

72. Le, CF, Yusof, MY, Hassan, MA, Lee, VS, Isa, DM, Sekaran, SD1. In vivo efficacy and molecular docking of designed peptide that exhibits potent antipneumococcal activity and synergises in combination with penicillin. Sci Rep. 2015; 9(5):11886. doi: 10.1038/srep11886.

73. Scott, MG, Dullaghan, E, Mookherjee, N et al. (2007). An anti-infective peptide that selectively modulates the innate immune response. Nature Biotechnology 2007; 25(4): 465-472

74, Neill DR, Coward WR, Gritzfeld JF, Richards L, Garcia-Garcia FJ, Dotor J, Gordon SB, Kadioglu A. Density and duration of pneumococcal carriage is maintained by transforming growth factor $\beta 1$ and T regulatory cells. Am J Respir Critare Med. 2014; 189(10):1250-1259

75. Habets MGJL, Brockhurst. MA. Therapeutic antimicrobial peptides may compromise natural immunity. Biol. Lett. (2012) 8, 416-418

76. Mansour, S, de la Fuente-Núñez, C, Hancock, REW. Peptide IDR-1018: modulating the immune system and targeting bacterial biofilms to treat antibiotic-resistant bacterial infections. J. Pept. Res. 2014; PMID: 25358509

77. Fuente-Núñez, C, Reffuveille, F, Haney, EF et al. Broad-spectrum anti-biofilm peptide that targets a cellular stress response. PLoS Pathogens 2014; 10(5): e1004152. 
78. Fuente-Núñez, CF, Reffuveille, L, Fernández, Hancock, REW. Bacterial biofilm development as a multicellular adaptation: Antibiotic resistance and new therapeutic strategies. Curr. Opinion Microbiol. 2013; 16:580-589

79. Teo, I, Toms, SM, Marteyn, B et al. Preventing acute gut wall damage in infectious diarrhoeas with glycosylated dendrimers. EMBO Molecular Medicine 2012; 4: 866-881

80. Seoka, J, Warren, HS, Cuencac, AG et al. Comparison of the transcriptional landscapes between human and mouse tissues. PNAS 2014; 111(48): 17224-17229

81. Teleman, D, Chung, C-S, Ayala, A et al. AB103, a CD28 antagonist peptide: a new therapeutic agent in a model of severe sepsis. Crit Care. 2011; 15(Suppl 3): P35.

82. Brown, KL, Cosseau, C, Gardy, JL, Hancock, REW. Complexities of targeting innate immunity to treat infection. TRENDS in Immunology 2007; 28(6) doi:10.1016/j.it.2007.04.005

83. Shankar, R, He, LK, Szilagy, A et al. A novel antibacterial gene transfer treatment for multidrug-resistant Acinetobacter baumannii-induced burn sepsis. J Burn Care Res. 2007; 28(1): 6-12

84. Williams, JJ, Hergenrother, PJ. Artificial activation of toxin-antitoxin systems as an antibacterial strategy. Trends Microbiol. 2012; 20(6): 291-8

85. Hale, L, Lazos, O, Haines, A, Thomas, C. An efficient stress-free strategy to displace stable bacterial plasmids. Biotechniques 2010; 48(3): 223-228

86. Deresinski, S. Bacteriophage therapy: exploiting smaller fleas. Clin Infect Dis. 2009; 48(8): 1096-1101

87. RJ Citorik, RJ, Mimee, M, Lu, K. Sequence-specific antimicrobials using efficiently delivered RNA-guided nucleases. Nature Biotechnology 2014; 32(11): 1141-1145

88. Bikard, D, Euler, SW, Jiang, W et al. Exploiting CRISPR-Cas nucleases to produce sequence-specific antimicrobials Nature Biotechnology 2014; 32(11): 1146-1150

89. McArthur, M, Bibb, MJ. Manipulating and understanding antibiotic production in Streptomyces coelicolor A3(2) with decoy oligonucleotides Proc Natl Acad Sci U S A. 2008; 105(3): 1020-5

90. Henry, BD, Neill, D, Becker, KA et al. Engineered liposomes sequester bacterial exotoxins and protect from severe invasive infections in mice. Nat Biotechnol. 2015; 33(1): 81-8

91. Stiefel, U, Pultz, NJ, Harmoinen, J et al. Oral administration of beta-lactamase preserves colonization resistance of Piperacillin-treated mice. Journal of Infectious Diseases 2003; 188: 1605-1609

92. Stiefel, U, Harmoinen, J, Koski, P et al. Orally administered recombinant metallo-beta -lactamase preserves colonization resistance of Piperacillin-Tazobactam-treated mice Antimicrob. Agents Chemother. 2005; 49(12): $5190-5191$

93. Harmoinen, J, Mentula, SM, Heikkilä, M et al. Beta-lactamase prevents Ampicillin-induced selective pressure on the gut microbiota: a novel approach to reducing antimicrobial resistance. Antimicrob. Agents Chemother. 2004; 48(1): 75-79

94. Tarkkanen, AM, Heinonen, T, Jogi, R et al. P1A Recombinant beta-lactamase prevents emergence of antimicrobial resistance in gut microflora of healthy subjects during intravenous administration of Ampicillin. Antimicrob. Agents Chemother. 2009; 53(6): 2455-2462

95. Luo, T, Spellberg, B, Gebremariam, T et al. Combination therapy with iron chelation and vancomycin in treating murine staphylococcemia. Eur J Clin Microbiol Infect Dis. 2014; 33: 845-851

96. Moreau-Marquis, A, O’Toole, GA, Stanton, BA. Tobramycin and FDA-approved iron chelators eliminate Pseudomonas aeruginosa biofilms on cystic fibrosis cells. Am J Respir Cell Mol Biol 2009; 41: 305-313 
97. Li, N, Xu, Y, Xia, Q et al. Simplified captopril analogues as NDM-1 inhibitors. BMCL 2014; 24: 386-389

98. Aoki, N, Ishii, Y, Tateda, K et al. Efficacy of Calcium-EDTA as an Inhibitor for Metallo-beta-lactamase in a mouse model of Pseudomonas aeruginosa pneumonia. Anti. Micro.Agents. Chemother. 2010; 54(11): 45824588

99. Yoshizumi, A, Ishii, Y, Livermore, DM et al. Efficacies of calcium-EDTA in combination with imipenem in a murine model of sepsis caused by Escherichia coli with NDM-1 b-lactamase. J Infect Chemother 2013; 19: 992-995

100. www.altermune.com

101. Wells, TJ, Whitters, D, Sevastsyanovich, YR et al. (2014) Increased severity of respiratory infections associated with elevated anti-LPS IgG2 which inhibits serum bactericidal killing. J. Exp. Med. 2014; 211(9): 1893-19042

102. Bangert, M, Bricio-Moreno, L, Gore, S et al. P4-mediated antibody therapy in an acute model of invasive pneumococcal disease. The Journal of Infectious Diseases 2012; 205:1399-1407

103. Morton, B, Pennington, SH, Gordon, SB. Immunomodulatory adjuvant therapy in severe community acquired pneumonia. Expert Review of Respiratory Medicine 2014; 8(5): 587-596

104. Fox, JL. Antimicrobial peptides stage a comeback. Nature Biotechnology 31; 379-382

105. Ladhani, SN, Campbell, H, Parikh, SR, Saliba, V, Borrow, R, Ramsay, M. The introduction of the meningococcal B (MenB) vaccine (Bexsero $\AA)$ into the national infant immunisation programme - New challenges for public health. J Infect. 2015; pii: S0163-4453(15)00313-8.

106. Islam, D, Lombardini, E, Ruamsap, N, Imerbsin, R, Khantapura, P, Teo, I, Neesanant, P, Gonwong, S, Yongvanitchit, K, Swierczewski, BE, Mason, CJ, Shaunak, S. Controlling the cytokine storm in severe bacterial diarrhea with an oral TLR4 antagonist. Immunology Accepted Article, 2015. doi: 10.1111/imm.12549

107. Gordon, YJ, Romanowski, EG. A Review of Antimicrobial Peptides and Their Therapeutic Potential as AntiInfective Drugs. Curr Eye Res. 2005; 30(7): 505-515

108. References were identified through searches of PubMed for articles to 27 February 2015, by use of terms "pharmacokinetic OR safety" with "human OR mouse OR rat" in combination with "host defense peptide"; Antibiofilm peptide"; "lantibiotic"; bacteriophage"; "lysin" and in the case of antimicrobial peptides "antimicrobial peptide" with "pharmacokinetic OR safety" and "E. coli OR P. aeruginosa OR C. difficile OR $S$. aureus" followed by inspection of the 238 papers listed

109. D. Andes, D, Craig, W, Nielsen, LA, Kristensen, HH. In vivo pharmacodynamic characterization of a novel plectasin antibiotic, NZ2114, in a murine infection model. Antimicrobial Agents and Chemotherapy 2009; 53(7); 3003-3009

110. Sidelmann Brinch, K, Sandberg, A, Baudoux, $\mathrm{P}$ et al. Plectasin shows intracellular activity against Staphylococcus aureus in human THP-1 monocytes and in a mouse peritonitis model. Antimicrobial Agents and Chemotherapy 2009; 53(11): 4801-4808

111. Pouillot, F, Chomton, M, Blois, H et al. Efficacy of bacteriophage therapy in experimental sepsis and meningitis caused by a clone O25b:H4-ST131 Escherichia coli strain producing CTX-M-15. Antimicrobial Agents and Chemotherapy 2012; 56(7) 3568-3575

112. Lepak AJ1, Marchillo K2, Craig WA1, Andes DR In Vivo Pharmacokinetics and Pharmacodynamics of the Lantibiotic NAI-107 in a Neutropenic Murine Thigh Infection Model Antimicrob Agents Chemother. 2015 Feb;59(2):1258-64

113. Ghobrial O1, Derendorf H, Hillman JD Pharmacokinetic and pharmacodynamic evaluation of the lantibiotic MU1140 J Pharm Sci. 2010 May;99(5):2521-8 
114. Bruttin A, Brussow H. Human Volunteers Receiving Escherichia coli Phage T4 Orally: a Safety Test of Phage Therapy. Antimicrobial Agents and Chemotherapy 2005; 49(7) 2874-2878

115. Holfeld, L, Herth, N, Singer, D, Hoffmann, R, Knappe, D. Immunogenicity and pharmacokinetics of short, proline-rich antimicrobial peptides. Future Med Chem. 2015; 7(12):1581-96

116. Docobo-Pérez, F, Drusano, GL, Johnson, A, Goodwin, J, Whalley, S, Ramos-Martín, V, Ballestero-Tellez, M, Rodriguez-Martinez, JM, Conejo, MC, van Guilder, M, Rodríguez-Baño, J, Pascual, A, Hope, WW. Pharmacodynamics of Fosfomycin: Insights into Clinical Use for Antimicrobial Resistance. Antimicrob Agents Chemother. 2015;59(9):5602-10

117. Rex, JH, Goldberger, M, Eisenstein, BI, Harney, C. The evolution of the regulatory framework for antibacterial agents. Ann. N.Y. Acad. Sci. (2014); 1323: 11-21

118. DiMasi, JA, Feldman, L, Seckler, A, Wilson A. Trends in risks associated with new drug development: success rates for investigational drugs. Clin Pharmacol Ther. 2010; 87(3): 272-277

119. Hernandez, LD, Racine, F, Xiao, L, DiNunzio, E, Hairston, N, Sheth, PR, Murgolo, NJ, Therien, AG. Broad coverage of genetically diverse strains of Clostridium difficile by actoxumab and bezlotoxumab predicted by in vitro neutralization and epitope modeling. Antimicrob Agents Chemother. 2015; 59(2):1052-60.

120. Morrison, C. Antibacterial antibodies gain traction. Nature Reviews Drug Discovery 2015; 14: 737-738.

121. http://www.aridispharma.com/

122. http://www.serestherapeutics.com/pipeline/ser-109

\section{3. http://www.rebiotix.com/}

124. Gerding, DN, Meyer, T, Lee, C, Cohen, SH, Murthy, UK, Poirier, A, Van Schooneveld, TC, Pardi, DS, Ramos, A, Barron, MA, Chen, H, Villano, S. Administration of spores of nontoxigenic Clostridium difficile strain M3 for prevention of recurrent C. difficile infection: a randomized clinical trial. JAMA. 2015; 313(17):1719-27

\section{5. http://www.ampliphibio.com/}

\section{6. http://www.cdiffense.org/}

127. Westritschnig, K, Hochreiter, R, Wallner, G, Firbas, C, Schwameis, M, Jilma, B. A randomized, placebocontrolled phase I study assessing the safety and immunogenicity of a Pseudomonas aeruginosa hybrid outer membrane protein OprF/I vaccine (IC43) in healthy volunteers. Hum Vaccin Immunother. 2014; 10(1):170-83.

128. http://www.valneva.com/

\section{9. https://clinicaltrials.gov/ct2/show/NCT02388165}

130. http://www.polyphor.com/products/pol7080

131. http://www.novactabio.com/

132. Paul, SM, Mytelka, DS, Dunwiddie, CT, et al. How to improve R\&D productivity: the pharmaceutical industry's grand challenge. Nat Rev Drug Discov. 2010; 9(3): 203-14

133. Sertkaya, A, Eyraud, E, Birkenbach, A et al. Analytical Framework for Examining the Value of Antibacterial Products. (http://aspe.hhs.gov/sp/reports/2014/antibacterials/rpt_antibacterials.cfm)

134. Scudiero, O, Nigro, E, Cantisani, M, Colavita, I, Leone, M, Mercurio, FA, Galdiero, M, Pessi, A, Daniele, A, Salvatore, F, Galdiero, S. Design and activity of a cyclic mini- $\beta$-defensin analog: a novel antimicrobial tool. Int J Nanomedicine. 2015; 10:6523-39

135. Pires, J, Siriwardena, TN, Stach, M, Tinguely, R, Kasraian, S, Luzzaro, F, Leib, SL, Darbre, T, Reymond, JL, Endimiani, A. In Vitro Activity of a Novel Antimicrobial Peptide Dendrimer (G3KL) Against Multidrug- 
Resistant Acinetobacter baumannii and Pseudomonas aeruginosa. Antimicrob Agents Chemother. 2015 Oct 12. pii: AAC.01853-15. [Epub ahead of print]

136. http://www.accessdata.fda.gov/drugsatfda_docs/label/2014/206829lbl.pdf

137. Zhanel, GG, Chung, $\mathrm{P}$, Adam, $\mathrm{H}$ et al. Ceftolozane/tazobactam: a novel cephalosporin/ $\beta$-lactamase inhibitor combination with activity against multidrug-resistant gram-negative bacilli. Drugs. 2014; 74(1): 31-51

138. Banerjee, R, Teng, CB, Cunningham, SA, Ihde, SM, Steckelberg, JM, Moriarty, JP, Shah, ND, Mandrekar, JN, Patel, R. Randomized Trial of Rapid Multiplex Polymerase Chain Reaction-Based Blood Culture Identification and Susceptibility Testing Clinical Infectious Diseases® 2015; 61(7):1071-80

139.

http://www.ema.europa.eu/ema/index.jsp?curl=pages/news_and_events/events/2015/05/event_detail_001155.js p\&mid=WC0b01ac058004d5c3\#details)

140. http://www.epibiome.com/

141. Report to the president on combating antibiotic resistance.

https://www.whitehouse.gov/sites/default/files/microsites/ostp/PCAST/pcast_carb_report_sept2014.pdf

142. https://en.wikipedia.org/wiki/Large_Hadron_Collider

143. https://en.wikipedia.org/wiki/International_Space_Station 